California State University, Monterey Bay

Digital Commons @ CSUMB

$10-2017$

\title{
California Mission Landscapes: Race, Memory, and the Politics of Heritage. Architecture, Landscape, and American Culture Series. By Elizabeth Kryder-Reid
}

Jennifer Lucido

California State University, Monterey Bay, jlucido@csumb.edu

Follow this and additional works at: https://digitalcommons.csumb.edu/sbgs_fac

\section{Recommended Citation}

Lucido, Jennifer, "California Mission Landscapes: Race, Memory, and the Politics of Heritage. Architecture, Landscape, and American Culture Series. By Elizabeth Kryder-Reid" (2017). SBGS Faculty Publications and Presentations. 26.

https://digitalcommons.csumb.edu/sbgs_fac/26

This Book Review is brought to you for free and open access by the Social Behavioral and Global Studies at Digital Commons @ CSUMB. It has been accepted for inclusion in SBGS Faculty Publications and Presentations by an authorized administrator of Digital Commons @ CSUMB. For more information, please contact digitalcommons@csumb.edu. 
California Mission Landscapes: Race, Memory, and Politics of Heritage. Architecture, Landscape, and American Culture Series. By Elizabeth Kryder-Reid. (Minneapolis: University of Minnesota Press, 2016. vx + 355 pp. Illustrations, maps, appendix, notes, bibliography, index. $\$ 122.50$, cloth; $\$ 35$, paper.)

In California Mission Landscapes: Race, Memory, and Politics of Heritage, Elizabeth Kryder-Reid examines the seeds of invented heritage of the Spanish missions of California. While most historians and archaeologists chronicle the built environment and layout of the California missions and presidios, Kryder-Reid explores the formation of the mission gardens. Over the past 150 years, the mission gardens have been synonymous with the "ancient," "sacred," and "romantic" heritage of Spanish colonialism. According to Kryder-Reid, these gardens not only perpetuate a fanciful Spanish colonial past but also contribute to the marginalization of Native Californians and their presence in the mission landscape.

Kryder-Reid traces the beginnings of the mission garden type in California through a rich array of primary sources. Her archival research demonstrates that the design template of the mission garden did not originate as a Spanish colonial tradition despite its omnipresence in the mission landscape. Rather, the mission garden flourished as a late 19th and early 20th century American creation influenced by Mediterranean themes. Central to the mission gardens are feelings of nostalgia and timelessness that conjure "Old World heritage transplanted to a new Eden" of California (141). The mission garden sets an idyllic stage in which the Franciscan friars are cast as benevolent caretakers of the land. Kryder-Reid argues that this (re)creation both legitimizes and glorifies the colonial history of California. The showcase of nonnative plants reinforces this imagined heritage without acknowledgement of the displacement and dispossession of Native Californians. Kryder-Reid contends that the propagation of the mission gardens as colonial relics is embedded into the cultural memory of the California missions.

From postcards to YouTube, tourism and commercialization have also played an integral role in the fabrication of cultural memory. Since the late 19th century, the missions have become destination sites for tourists, fourth grade students, and pilgrims. The visitor experience 
at the missions is shaped through scripted tours and guided walkthroughs thereby reinforcing the colonial undertones of the mission landscape. More recently, some missions have made concerted efforts to recognize and incorporate the indigenous presence in the mission landscape through the cultivation of native plants, construction of prehistoric dwellings, and consultation with tribal communities. Despite this, Kryder-Reid remains unwavering in her argument that such objectifies and appropriates indigenous culture into a Western garden tradition. Such interpretation minimizes the evolving representations of mission heritage and the collaboration with Native Californian descendants and stakeholders who helped facilitate this change. Furthermore, Kryder-Reid omits any discussion of the tribal politics that additionally complicate how mission landscapes are interpreted. Kryder-Reid's strengths lie with her detailed interrogation of mission gardens, and California mission heritage more broadly, as well as her ability to foster dialogue about colonialism and the formation of cultural memory.

Jennifer Lucido

California State University, Monterey Bay

School of Social, Behavioral \& Global Studies

California State University, Monterey Bay

100 Campus Center

Seaside, California 93955

831-236-1252

jlucido@csumb.edu 